\title{
Intracerebral Hemorrhage as a Surgical Challenge-Where Should We Focus?
}

\section{Frosen, Juhana}

2016-07

Frosen , J , Rezai Jahromi , B \& Hernesniemi , J 2016 , ' Intracerebral Hemorrhage as a Surgical Challenge-Where Should We Focus? ' , World Neurosurgery , vol. 91 , pp. 638-639 . https://doi.org/10.1016/J.WNEU.2016.04.068

http://hdl.handle.net/10138/224567

https://doi.org/10.1016/J.WNEU.2016.04.068

publishedVersion

Downloaded from Helda, University of Helsinki institutional repository.

This is an electronic reprint of the original article.

This reprint may differ from the original in pagination and typographic detail.

Please cite the original version. 


\title{
Intracerebral Hemorrhage as a Surgical Challenge-Where Should We Focus?
}

\author{
Juhana Frösen ${ }^{1}$, Behnam Rezai Jahromi, Juha Hernesniemi²
}

$\mathrm{H}$ emorrhage to the brain parenchyma is an important cause of mortality and morbidity, causing a significant economic burden related to loss of productive years and health care costs ${ }^{1}$ in addition to human suffering.

\section{REMOVAL OF HEMORRHAGIC MASS-IS THAT SUFFICIENT?}

Intracerebral hemorrhage $(\mathrm{ICH})$ 1) lacerates the brain parenchyma and disrupts white matter tracts; 2) causes mass effect and disturbs the function of neighboring white matter tracts or cortical regions; and 3) releases molecules that induce inflammation and oxidative stress, which creates a tissue microenvironment that predisposes to death of neurons. ${ }^{2-4}$ Because of the aforementioned deleterious effects of $\mathrm{ICH}$, it would seem logical that removal of $\mathrm{ICH}$ would reduce the degree of secondary parenchymal damage caused by mass effect and toxicity of clot breakdown products. However, the neurologic impairment left by the $\mathrm{ICH}$ is not only related to the mass effect but also to the disruption of white matter tracts or destruction of cortical regions, basal ganglia, thalamus, cerebellum, or brainstem during the acute bleeding. Moreover, it is unknown to what extent the inflammation and oxidative stress triggered by the presence of blood in the parenchyma affects the degree of neuronal damage and outcome of the patient despite evacuation of the blood clot. Experiments in animal models suggest that pharmaceutical or other biologic therapy against the toxic effects of clot-derived iron may improve the outcome of patients with $\mathrm{ICH}^{2-4}$ This suggests that the major improvements in the management and outcome of patients with $\mathrm{ICH}$ may come from research focused on the biology of $\mathrm{ICH}$-induced brain injury.

\section{TO OPERATE OR NOT ON AN ICH-WHICH PATIENT BENEFITS?}

Neurosurgeons know from experience and clinical series that some patients benefit from removal of $\mathrm{ICH}$, but others do not. This situation is well demonstrated by the fact that guidelines written by experts recommend consideration of surgery in certain clinical scenarios of acute $\mathrm{ICH}$ despite the difficulty of demonstrating the benefit in randomized clinical trials. ${ }^{5}$ How to identify patients who truly benefit from $\mathrm{ICH}$ removal in the long-term remains an unanswered challenge. Despite the large number of studies published on the topic, further research is still required, especially as the introduction of novel minimally invasive surgical techniques ${ }^{6}$ may significantly reduce the risk of causing additional neuronal injury with surgical approach.

\section{TO USE MOTOR EVOKED POTENTIALS OR NOT IN ICH SURGERY-} IS THERE A BENEFIT?

Intraoperative use of motor evoked potentials (MEPs) to monitor that the pyramidal tract stays intact during surgery is a widely used and well-established technique that increases the safety of many kinds of intracranial operations. The primary purpose of intraoperative MEP monitoring is to alert the surgeon that his or her actions are damaging the pyramidal tract so that the surgeon can alter his or her actions to avoid causing further injury.

The article by lkedo et al. on the use of MEP monitoring during $\mathrm{ICH}$ surgery is innovative, but it raises the question of clinical utility. The authors state that in none of their cases did the MEPs change during surgery, and they did not report that they would have altered their surgical strategy or actions during the operation because of the MEP findings. Although it is possible to cause

\author{
Key words \\ - Hemiparesis \\ - Intracerebral hemorrhage \\ - Motor-evoked potential \\ - Motor function \\ - Prediction \\ - Prognosis
}

\author{
Abbreviations and Acronyms \\ ICH: Intracerebral hemorrhage \\ MEP: Motor evoked potential \\ STICH: Surgical Trial in \\ Intracerebral Haemorrhage
}

From the ${ }^{1}$ Department of Neurosurgery, Kuopio University Hospital, Kuopio; and ${ }^{2}$ Department of Neurosurgery, Helsinki University Hospital, Helsinki, Finland

To whom correspondence should be addressed: Juha Hernesniemi, M.D., Ph.D.

[E-mail: juha.hernesniemi@icloud.com]

Citation: World Neurosurg. (2016) 91:638-639

http://dx.doi.org/10.1016/j. wneu.2016.04.068 
further injury to the pyramidal tract during $\mathrm{I} C H$ removal, the main determinant of functional outcome is the degree of damage caused to the pyramidal tract by the hematoma itself, which is what the results of Ikedo et al. also demonstrate. Similar conclusions are suggested by results of the International Surgical Trial in Intracerebral Haemorrhage (STICH) trial, in which surgery did not significantly improve functional outcome of survivors, ${ }^{7}$ as well as by observations from a large population-based Finnish $\mathrm{ICH}$ registry study, in which surgery for $\mathrm{ICH}$ reduced mortality but did not significantly improve functional outcome of survivors. ${ }^{8}$

Because the surgeon avoids any transgression of the white matter as much as possible during $\mathrm{ICH}$ surgery, with the exception of sometimes having to coagulate a site of active bleeding, it is not apparent how intraoperative MEP recordings would change the surgical strategy-certainly one would not leave a site of active bleeding unattended. The finding that MEP measurements predict recovery of hemiparesis is not surprising; rather, it is the expected finding. How the ability to better predict recovery of hemiparesis will improve clinical practice is an open question to which the answer likely varies in different societies and cultures. However, in most instances, one would continue maximal rehabilitation and physical therapy in the immediate postoperative period despite signs of severe damage to the pyramidal tract. In a later phase, the clinical progression of the hemiparesis will reveal the degree of injury to the pyramidal tract as well as the ability to recover without any MEP recordings.

\section{ICH AS A SURGICAL CHALLENGE-WHERE TO FOCUS?}

Although it describes an innovative approach to study the use of MEP monitoring during $\mathrm{ICH}$ removal, the article by lkedo et al leaves open the question of what the benefit of MEP monitoring would be. Instead of predicting functional outcome in the early postoperative period, identification of patients who benefit from surgery remains the main challenge in the treatment of $\mathrm{ICH}$. In addition, we should focus on the translation of the knowledge learned from animal models of $\mathrm{ICH}$ into biologic therapies that reduce the extent of $\mathrm{ICH}$-induced neuronal injury in patients.

\section{REFERENCES}

I. Taylor TN, Davis PH, Torner JC, Holmes J, Meyer JW, Jacobson MF. Lifetime costs of stroke in the United States. Stroke. I996;27:I459-I466.

2. Duan $X$, Wen $Z$, Shen $H$, Shen $M$, Chen G. Intracerebral hemorrhage, oxidative stress, and antioxidant therapy [e-pub ahead of print] Oxid Med Cell Longev; 20I6. http://dx.doi.org/Io.II55/20I6/ I203285.

3. Okauchi M, Hua Y, Keep RF, Morgenstern LB, Xi G. Effects of deferoxamine on intracerebral hemorrhage-induced brain injury in aged rats. Stroke. 2009;40:1858-1863.

4. Wakai T, Sakata H, Narasimhan P, Yoshioka H, Kinouchi H, Chan PH. Transplantation of neural stem cells that overexpress SODI enhances amelioration of intracerebral hemorrhage in mice. J Cereb Blood Flow Metab. 20I4;34:44I-449.

5. Morgenstern LB, Hemphill JC, Anderson C, Becker K, Broderick JP, Connolly ES, et al. Guidelines for the management of spontaneous intrace rebral hemorrhage: a guideline for healthcare professionals from the American Heart Association/American Stroke Association. Stroke. 20I0;4I: 2I08-2I29.

6. Spiotta AM, Fiorella D, Vargas J, Khalessi A, Holt D, Arthur A, et al. Initial multicenter technical experience with the Apollo device for minimally invasive intracerebral hematoma evacuation. Neurosurgery. 2015;II:243-25I.

7. Mendelow $\mathrm{AD}$, Gregson $\mathrm{BA}$, Fernandes HM, Murray GD, Teasdale GM, Hope DT, et al. Early surgery versus initial conservative treatment in patients with spontaneous supratentorial intracerebral haematomas in the International Surgical Trial in Intracerebral Haemorrhage (STICH): a randomised trial. Lancet. 2005;365:387-397.

8. Löppönen P, Tetri S, Juvela S, Huhtakangas J Saloheimo P, Bode MK, et al. A population based study of outcomes after evacuation of primary supratentorial intracerebral hemorrhage. Clin Neurol Neurosurg. 2013;II5:I350-I355.

Citation: World Neurosurg. (2016) 91:638-639. http://dx.doi.org/10.1016/j.wneu.2016.04.068

Journal homepage: www.WORLDNEUROSURGERY.org

Available online: www.sciencedirect.com

1878-8750/\$ - see front matter (C) 2016 Elsevier Inc. All rights reserved. 